\title{
Community-Based Consumable Fresh Water in Coastal Area of Dente Teladas Village, Tulang Bawang District, Lampung Province
}

\author{
Endang L. Widiastuti ${ }^{1,2}$ Vina O. Indraswati ${ }^{1, *}$ Indra G. Febryano ${ }^{1}$ Hartoyo $^{1}$ \\ Supono ${ }^{1}$ \\ ${ }^{1}$ Graduate School of Coastal and Marine Management, Universitas Lampung, Bandar Lampung, Indonesia \\ ${ }^{2}$ Coastal and Marine Research Center, Universitas Lampung, Bandar Lampung, Indonesia \\ *Corresponding author. E-mail: vina.indraswati@gmail.com
}

\begin{abstract}
Community access to consumed water in most coastal areas is still limited, which is one of the causes of the low level of welfare. The aim of the study was to explain the perceptions of coastal communities in Dente Teladas Village of Tulang Bawang District-Lampung Province towards the provision of water facilities, infrastructure, and institutional effectiveness. The data collection used purposive sampling technique with questionnaire from 100 respondents of beneficary community and other related stakeholders. Obtaining data were analyzed with Likert scale and described for the perception of the provision of water facilities, infrastructure, and institutional effectiveness. The results of the study indicated that the community's perception of the facilities and infrastructure was good, the community had willingness to pay contributions, and management institution was effectively run. This could be seen from the existence of norms, organizations which actively run and institutionalized supported by the capacity of administrators and members, level of trust, level of compliance, level of participation, and high level of public understanding of the applicable rules. In addition, government policies, management policies, strengthening institutional structures, programs to increase the capacity of managers and rehabilitation of water facilities and infrastructure also increased the effectiveness of existing institutions. It was nationally expected then to accelerate the development of water facilities and infrastructure in coastal areas, therefore every coastal community could get access to consumable/drinking water and in return could improve their welfare.
\end{abstract}

Keywords: Institutions, community-based consumable freshwater, freshwater management, coastal areas

\section{INTRODUCTION}

The coastal region is an area with fairly rapid growth and relatively inexpensive compared to land space. Almost $60 \%$ of the population in big cities spreads to the coast [1]. Abundant of natural resources that are not accompanied by good human resources make coastal areas vulnerable to poverty.

Based on data from the Central Statistics Agency [2], around $21.1 \%$ of the total population of Indonesia do not yet have access to clean water. This relates to the problem of water supply or water pressure that is unable to reach the coastal area [3].

Management water based on community has been carried out by involving stakeholders in the society from the planning process, development to the evaluation process of the results [4]. Society participation can be interpreted as participation in planning activities, and society willingness to contribute to the implementation of development programs [5].

The level success in implementing water supplybased society is determined by better quality, quantity and continuity as well as the formation of community groups that are able to carry out the development of drinking water supply systems independently and sustainably [6]. This research aims to explain the public perception of the provision of water facilities and infrastructure and institutional effectiveness. Data collection was carried out interviews using a questionnaire, observation, and desk study of related documents. 


\section{METHODS}

The sampling technique in this research is purposive sampling from beneficiary community and other related stakeholders. Taking the number of samples using the Slovin formula and obtained a total sample of 100 respondents.

Collected data then analyzed perception using a Likert Scale. In this research, the scores given for the Likert Scale are as shown in Table 1.

Table 1. Scoring with Likert Scale

\begin{tabular}{|l|c|}
\hline \multicolumn{1}{|c|}{ Answer option } & Score \\
\hline Strongly Agree (SA) & 3 \\
Agree (A) & 2 \\
Disagree (D) & 1 \\
\hline
\end{tabular}

In this study, the percentage obtained from the tabulated data of this research uses the interpretation of the criteria as shown in Table 2.

Table 2. Percentages with Likert Scale

\begin{tabular}{|c|c|}
\hline Presentation & Classification \\
\hline $90 \%-100 \%$ & Very High \\
$80 \%-89 \%$ & High \\
$70 \%-79 \%$ & High Enough \\
$60 \%-69 \%$ & Medium \\
$50 \%-59 \%$ & Low \\
$49 \%$ & Very Low \\
\hline
\end{tabular}

\section{RESULT AND DISCUSSION}

Based on questionnaire from 100 respondents, society perceptions of the provision of water facilities and infrastructure can be seen in Table 3 .

The perception of coastal society towards water supply facilities and infrastructure is based on observed variables, such as facilities and infrastructure environment. While the indicators of the facilities and infrastructure variables are the existing of a secretariat office, administrative completeness, the availability of technical equipment for maintenance and repair of networks, utilization of water sources and debits. Whereas indicators for environmental service parameters are the societies willingness to pay monthly fees, the availability of monthly operational funds for administrators and maintenance of clean water networks, and other funds.

In Table 3, it is stated that $61.2 \%$ of the respondents agreed that society-based water management facilities and infrastructure are established. This can be seen with the existence of a secretariat office, administrative equipment and technical equipment. With these facilities and infrastructure, it is expected that supporting of consumable freshwater/drinking water supply activities for the Sungai Nibung community is provided. Whereas $52.8 \%$ of respondents strongly agreed that the availability of water was able to meet the water needs of the beneficiary society.

Table 3. Society perceptions of the provision of water facilities and infrastructure

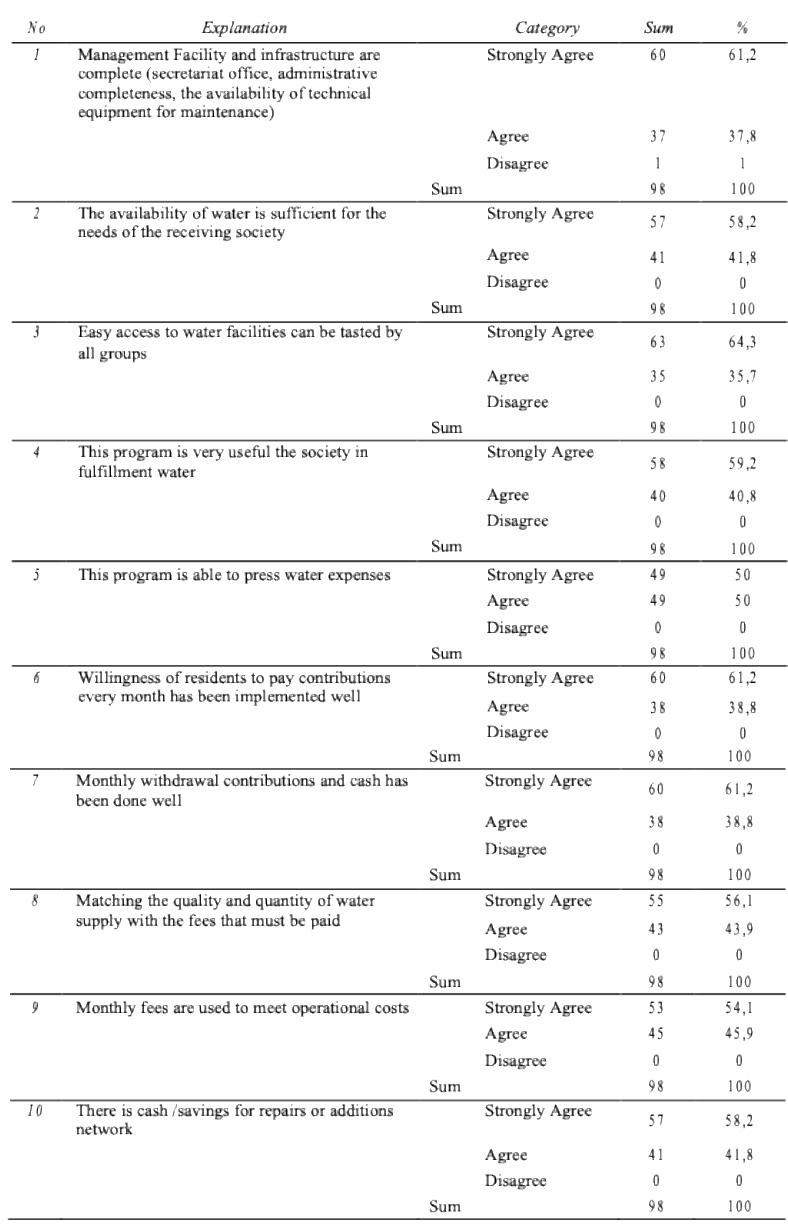

Easy access to drinking water has also been tasted by all levels of society and this program can assist in efforts to meet the needs of water in the Sungai Nibung. This is seen from $46.3 \%$ of respondents who strongly agree with this. The community is very enthusiastic about this program, because previously there was no program to construct clean water facilities and infrastructure, as seen from $59.2 \%$ of respondents strongly agreed that this program can help meet the societies water needs, especially during dry season.

In table 3 also indicates that $50.0 \%$ of respondents strongly agree that this program can reduce monthly expenditure on water. The expected output with reducing costs for water is to improve the level of welfare of coastal societies, especially in the Sungai Nibung. This is because the society can allocate the cost 
of fulfilling water supply for other needs. As many as $61.2 \%$ of respondents already have the willingness to pay monthly fees well. They were charged for 1500 $\mathrm{IDR} / \mathrm{m}^{3}$ which was calculated based on the water use of each person by using a water meter. This monthly fee then is used to meet the monthly operational water management costs. Respondents also agreed that the withdrawal of monthly contributions and cash has been done well by the manager. Mandatory contributions or cash amounting to 5000 IDR charged to all users must be paid every month even if the user does not use water. As many as $58.2 \%$ of respondents strongly agreed that the cash collected every month is used as a backup fee if at any time there is some trouble with water facilities and for the addition of water supply networks.

The distribution of consumable freshwater in the Sungai Nibung has been running smoothly and the availability of water is sufficient to meet the needs of the beneficiary society. This can be seen from $56.1 \%$ of respondents who agreed that the amount of contributions to be paid was in accordance with the quality and quantity. This is also in accordance with $54.1 \%$ of respondents strongly agree that operational costs such as electricity, fuel, and the operational costs of the management can be met with monthly fees. With this program, it can run sustainably as an effort by the government to help all levels of society get access to adequate consumable fresh water. The society perception toward effectiveness of community-based water management can be seen in Table 4 as follows.

Table 4. Percentage of result of community-based water institutional effectiveness

\begin{tabular}{|c|c|c|c|c|}
\hline No & Explanation & Category & Sum & $\%$ \\
\hline \multirow[t]{4}{*}{1} & \multirow{4}{*}{$\begin{array}{l}\text { Does the group of management facility and } \\
\text { infrastructure water and Sanitations have } \\
\text { AD/ART or other written rules? }\end{array}$} & Strongly Agree & 64 & 65,3 \\
\hline & & Agree & 25 & 25,5 \\
\hline & & Disagree & 9 & \\
\hline & & Sum & 98 & \\
\hline \multirow[t]{4}{*}{2} & \multirow{4}{*}{$\begin{array}{l}\text { Is the enforcement of rules by the Water and } \\
\text { Sanititaion Facilities and Infrastructure } \\
\text { Management Group (KPSPAMS) going well? }\end{array}$} & Strongly Agree & 51 & 52 \\
\hline & & Agree & 37 & \\
\hline & & Disagree & 10 & 10,2 \\
\hline & & & 98 & \\
\hline \multirow[t]{4}{*}{3} & \multirow{4}{*}{$\begin{array}{l}\text { Does the Water and Sanitation Facilities and } \\
\text { Infrastructure Management Group } \\
\text { (KPSPAMS) have an organizational structure? }\end{array}$} & Strongly Agree & 48 & 49,0 \\
\hline & & & 40 & \\
\hline & & Disagree & 10 & 10,2 \\
\hline & & Sum & 98 & 1 \\
\hline \multirow[t]{3}{*}{4} & \multirow{3}{*}{$\begin{array}{l}\text { Does the Water and Sanitation Facilities and } \\
\text { Infrastructure Management Group (KPSPAMS) } \\
\text { manage the finance administration and network } \\
\text { expansion(technical) properly? }\end{array}$} & Strongly Agree & 50 & 51 \\
\hline & & & 39 & \\
\hline & & $\begin{array}{c}\text { Disagree } \\
\text { Sum }\end{array}$ & 98 & 9 \\
\hline \multirow[t]{3}{*}{5} & \multirow{3}{*}{ Do you obey to pay monthly fee? } & Strongly Agree & 44 & 44,9 \\
\hline & & & 43 & \\
\hline & & Disagree & 11 & 11,2 \\
\hline \multirow{4}{*}{6} & \multirow{4}{*}{$\begin{array}{l}\text { Do you belive that other user obey to pay } \\
\text { monthly fee? }\end{array}$} & Strongly Agree & 57 & $\frac{10}{58,}$ \\
\hline & & & 31 & 31, \\
\hline & & Disagree & 10 & 10,2 \\
\hline & & Sum & 98 & 100 \\
\hline \multirow[t]{4}{*}{7} & \multirow{4}{*}{$\begin{array}{l}\text { Do you obey the rule that made by Water and } \\
\text { Sanititaion Facilities and Infrastructure } \\
\text { Management Group (KPSPAMS)? }\end{array}$} & Strongly Agree & 57 & 58,2 \\
\hline & & Agree & 31 & \\
\hline & & Disagree & 10 & 10,2 \\
\hline & & Sum & 98 & 100 \\
\hline \multirow[t]{4}{*}{8} & \multirow{4}{*}{$\begin{array}{l}\text { Does the society participate in any drinking } \\
\text { water management activities (thoughts, energy, } \\
\text { costs)? }\end{array}$} & Strongly Agree & 46 & 46,9 \\
\hline & & Agree & 42 & 42,9 \\
\hline & & Disagree & 10 & 10,2 \\
\hline & & Sum & 98 & 100 \\
\hline \multirow[t]{4}{*}{9} & \multirow{4}{*}{$\begin{array}{l}\text { Will you protect the water facilities and } \\
\text { infrastructures o that this program can take } \\
\text { place in a sustainable manner? }\end{array}$} & Strongly Agree & 49 & 50,0 \\
\hline & & Agree & 47 & 48,0 \\
\hline & & Disagree & 2 & 2,0 \\
\hline & & Sum & 98 & 100 \\
\hline \multirow[t]{4}{*}{10} & \multirow{4}{*}{$\begin{array}{l}\text { Are there technical and administrative training } \\
\text { and training and maintenance activities from } \\
\text { stakeholders and related agencies? }\end{array}$} & Strongly Agree & 48 & 49,0 \\
\hline & & Agree & 43 & 43,9 \\
\hline & & Disagree & 7 & 7,1 \\
\hline & & Sum & 98 & 100 \\
\hline
\end{tabular}

Institutional effectiveness is determined by the effectiveness of social interactions that include participation in the process of making regulations so as to create a sense of ownership and communication, information, interpretation and understanding of the contents of regulations that involve knowledge and experience as well as networks of power that exist in society [7]. Local institutions have a very important role in resource management. Participatory organizations in local institutions have an important role when implementing rules in resource management. Active organization and community participation are efforts in developing joint strategies to plan sustainable resource development [8][9][10].

To determine the effectiveness of communitybased freshwater management bodies in the Sungai Nibung, several parameters are observed. The parameter is indicated by the existence of basic regulation and other written rules. As many as $65.3 \%$ of respondents strongly agree with the existence of a strong legal force regarding institutions that manage community-based consumable freshwater facilities and infrastructure. This rule is made so that the beneficiary community understands their rights and obligations. As many as $52 \%$ strongly agree that the enforcement of the rules of the water management group has gone well. Enforcement of the rules has been going well with the existence of a punishment system that refers to laws, regional regulations relating to the construction of clean water facilities and infrastructure, as well as the prevailing norms.

The water management agency also has an organizational structure that has different duties and responsibilities. It can be seen that $49 \%$ of respondents strongly agree that the group managing consumable/drinking water facilities and infrastructure has an organizational structure that is not only constructed, but also institutionalized. It is expected that with the division of labor, water management activities will be improved.

The Duty of the management group is to actively deal with every problem that arises, as well as managing the technical and administrative aspects, such as through the sterilization of the main network, the functioning of the reservoir in the distribution of additional network water, the functioning of the secretariat office, as well as the level of distribution of duties and responsibilities between the chairman and members. Active leadership indicated by $51.0 \%$ of respondents with strongly agree in which the Society Based Water Supply and Infrastructure Management Group (KPSPAMS) can manage administration/ finance and network expansion well. The parameters observed to indicate the level of community trust in the management group is high enough, it can be seen from $49.0 \%$ of respondents who strongly agreed to obey 
monthly fees and $58.2 \%$ strongly agreed that other communities also obey monthly fees. Another indicator of compliance level is shown by $58.2 \%$ of respondents strongly agree to obey the rules made by the management group. And $50.0 \%$ of respondents strongly agree to be able to maintain community-based consumable freshwater facilities and infrastructure so that it can take place in a sustainable manner.

The effectiveness of the water management agency is also seen from the level of society participation can be seen in the form of participation in thought, energy, funding, decision making, and the process. As many as $46.9 \%$ of respondents strongly agreed that the Sungai Nibung society had participated in every activity carried out by the management group. Whereas the observed indicators of the capacity building program for members and the user society are training in community based water management that is more professional, independent, and sustainable. This is indicated by $49 \%$ of respondents strongly agree that there is training and technical and administrative guidance from the department and related stakeholders. This form of community-based freshwater then possibly should be transferred to other coastal regions of Indonesia which has similar problem with consumable freshwater scarcity.

\section{CONCLUSION}

The conclusion from the society/community perception of coastal consumable freshwater facilities and infrastructure has positive perception. While indicators for the effectiveness of community-based freshwater management bodies also indicate good effectiveness.

\section{REFERENCES}

[1] Zain,M. Manajemen Perpajakan. Salemba Empat - Jakarta. 2007. 412 pp.

[2] Central Bureau of Statistics. Statistics of Indonesia. 2007. Jakarta: Statistics Indonesia.

[3] Ayunita, D. Analysis of Perception and People's Participation in Ujungnegoro KKLD Management, Batang Regency. Faculty of Fisheries and Marine Sciences, Diponegoro University. 2012.

[4] Abe, A. Participatory Regional Planning. 2001. Solo: Pondok Education

[5] Adisasmita, R. Building a Participatory Village. Yogyakarta: Daud Graha Science Publisher. 2006.

[6] Anwar. Fundamentals of Environmental Health. Department of Environmental Health FKM Unhas. 1999.
[7] Research Development Agency - Indonesian Infrastructure Ministry. Pedoman Penyelidikan geotehnik untuk fondasi bangunan air (Badan Litbang Departemen Pekerjaan Umum - Jakarta). 2005.

[8] Ribot J.C, Peluso NL. A Theory of Access. Rural Sociology 68(2). 2003. pp: 153-181.

[9] C. Febryano, I. G., D. Suharjito, D. Darusman., Kusmana, and A. Hidayat. Actor and Power Relations in Mangrove Management in Pesawaran Regency, Lampung Province, Indonesia. Journal of Forestry Policy Analysis. 12 (2). 2015. Pp. 125-142.

[10] Salampessy, M. L., Bone, I., \& Febryano, I. Dusung Nutmeg Performance as One of the Traditional Agroforestry in Maluku. Tengkawang. Journal of Forestry Social and Economic Research Vol. 14 No.2, 2017: 135-142 